\title{
Angiotensin Type 1a Receptors in the Paraventricular Nucleus of the Hypothalamus Protect against Diet-Induced Obesity
}

\author{
Annette D. de Kloet, ${ }^{1}$ Dipanwita Pati, ${ }^{3}$ Lei Wang, ${ }^{3}$ Helmut Hiller, ${ }^{3}$ Colin Sumners, ${ }^{1}$ Charles J. Frazier, ${ }^{3}$ Randy J. Seeley, ${ }^{4}$ \\ James P. Herman, ${ }^{2}$ Stephen C. Woods, ${ }^{2}$ and Eric G. Krause ${ }^{3}$ \\ ${ }^{1}$ Department of Physiology and Functional Genomics, College of Medicine, University of Florida, Gainesville, FL 32611, ${ }^{2}$ Department of Psychiatry and \\ Behavioral Neuroscience, College of Medicine, University of Cincinnati, Cincinnati, Ohio 45221, ${ }^{3}$ Department of Pharmacodynamics, College of Pharmacy, \\ University of Florida, Gainesville, Florida, 32611, ${ }^{4}$ Department of Internal Medicine, Division of Endocrinology, College of Medicine, University of \\ Cincinnati, Cincinnati, Ohio 45221
}

Obesity is associated with increased levels of angiotensin-II (Ang-II), which activates angiotensin type la receptors (AT ${ }_{1 \mathrm{a}}$ ) to influence cardiovascular function and energy homeostasis. To test the hypothesis that specific $\mathrm{AT}_{1 \mathrm{a}}$ within the brain control these processes, we used the Cre/lox system to delete $\mathrm{AT}_{1 \mathrm{a}}$ from the paraventricular nucleus of the hypothalamus (PVN) of mice. $\mathrm{PVN}_{\mathrm{AT}}$ deletion did not affect body mass or adiposity when mice were maintained on standard chow. However, maintenance on a high-fat diet revealed a gene by environment interaction whereby mice lacking $\mathrm{AT}_{1 \mathrm{a}}$ in the PVN had increased food intake and decreased energy expenditure that augmented body mass and adiposity relative to controls. Despite this increased adiposity, PVN AT $\mathrm{Pa}_{1 \mathrm{a}}$ deletion reduced systolic blood pressure, suggesting that this receptor population mediates the positive correlation between adiposity and blood pressure. Gene expression studies revealed that $\mathrm{PVN} \mathrm{AT}_{1 \mathrm{a}}$ deletion decreased hypothalamic expression of corticotrophin-releasing hormone and oxytocin, neuropeptides known to control food intake and sympathetic nervous system activity. Whole-cell patch-clamp recordings confirmed that $\mathrm{PVN} \mathrm{AT}_{1 \mathrm{a}}$ deletion eliminates responsiveness of PVN parvocellular neurons to Ang-II, and suggest that Ang-II responsiveness is increased in obese wild-type mice. Central inflammation is associated with metabolic and cardiovascular disorders and PVN AT $\mathrm{P}_{1 \mathrm{a}} \mathrm{deletion}$ reduced indices of hypothalamic inflammation. Collectively, these studies demonstrate that $\mathrm{PVN} \mathrm{AT}_{1 \mathrm{a}}$ regulate energy balance during environmental challenges that promote metabolic and cardiovascular pathologies. The implication is that the elevated Ang-II that accompanies obesity serves as a negative feedback signal that activates PVN neurons to alleviate weight gain.

\section{Introduction}

Body weight is maintained by endocrine and neural signals that act in the hypothalamus to coordinate the amount of energy consumed with that expended. Recently, the renin-angiotensinsystem (RAS) has emerged as a potential mediator of the hypothalamic control of body weight (Grobe et al., 2010; de Kloet et al., 2011b). Obese humans and animals have increased RAS activity resulting in elevated levels of angiotensin-II (Ang-II) (Cooper et al., 1998; Boustany et al., 2004; Rahmouni et al., 2004), which stimulates angiotensin type 1a receptors $\left(\mathrm{AT}_{1 \mathrm{a}}\right)$ in a variety of tissues including the brain (de Kloet et al., 2010). Transgenically (e.g., via the coexpression of human renin and angiotensinogen in mice) or pharmacologically augmenting central

Received Aug. 8, 2012; revised Jan. 2, 2013; accepted Jan. 29, 2013.

Author contributions: A.D.d.K., C.S., C.J.F., R.J.S., J.P.H., S.C.W., and E.G.K. designed research; A.D.d.K., D.P., L.W., H.H., C.J.F., and E.G.K. performed research; C.S. and R.J.S. contributed unpublished reagents/analytic tools; A.D.d.K., C.J.F., J.P.H., S.C.W., and E.G.K. analyzed data; A.D.d.K., C.J.F., J.P.H., S.C.W., and E.G.K. wrote the paper.

This work was supported by the National Institutes of Health (NIH) grants HLO96830 (E.G.K.), NIH NS068122 and HL083810 (A.D.d.K.), and NIH DK078201 (S.C.W.).

Corresponding author: Dr. Eric G. Krause, Assistant Professor, Department of Pharmacodynamics, College of Pharmacy, University of Florida, Gainesville, FL 32611. E-mail: ekrause@cop.ufl.edu.

DOI:10.1523/JNEUROSCI.3806-12.2013

Copyright $\odot 2013$ the authors $\quad 0270-6474 / 13 / 334825-09 \$ 15.00 / 0$
RAS activity promotes decreased body weight by inhibiting food intake and elevating energy expenditure (Porter et al., 2003; Furuhashi et al., 2004; Porter and Potratz, 2004; de Kloet et al., 2009, 2011b; Grobe et al., 2010). Thus, while it is clear that augmenting brain RAS activity to perhaps supraphysiological levels promotes negative energy balance, the role that central angiotensinergic circuits play in the physiological regulation of body weight subsequent to metabolic challenges that promote obesity and enhance RAS activity has not been discerned, nor has been the neural mechanism(s) underlying these effects. We hypothesized that exposure to an obesogenic environment increases $\mathrm{AT}_{1 \mathrm{a}}$ activation within the brain to decrease food intake and increase energy expenditure, and consequently, to alleviate weight gain.

Neurons within the paraventricular nucleus of the hypothalamus (PVN) are well suited to mediate the effects of Ang-II on body weight regulation. Parvocellular neurons within the PVN are known to influence food intake and energy expenditure (Woods and D'Alessio, 2008) and these same neurons also robustly express $\mathrm{AT}_{1 \mathrm{a}}$ (Lenkei et al., 1997). Consequently, $\mathrm{AT}_{1 \mathrm{a}}$ on PVN neurons may represent the mechanism and site of action underlying Ang-II mediation of energy balance. The present studies used the Cre/lox system in mice to delete the $\mathrm{AT}_{1 \mathrm{a}}$ ex- 
pressed on PVN neurons. Subsequently, the contribution of this receptor population to the regulation of energy balance was determined during maintenance on standard low-fat chow as well as during the consumption of increased dietary fat, a manipulation that facilitates weight gain and enhances RAS activity (Boustany et al., 2004). These studies reveal that deletion of $\mathrm{AT}_{1 \mathrm{a}}$ specifically within the PVN exacerbates diet-induced obesity.

\section{Materials and Methods}

Animals. PVN AT $1 \mathrm{a}$ KO mice were generated by crossing $\mathrm{AT}_{1 \mathrm{a}}$ flox mice (obtained from Dr. Alan Daugherty, University of Kentucky; Li et al., 2011) on a C57BL/6 background with Sim1Cre mice (generated by Dr. B. Lowell, Beth Israel Deaconess Medical Center and Harvard Medical School; Balthasar et al., 2005) on a C57BL/6 × 129 background. Male $\mathrm{PVN} \mathrm{AT}_{1 \mathrm{a}} \mathrm{KO}$ mice (homozygous for $\mathrm{AT}_{1 \mathrm{a}}$ flox $\left[\mathrm{AT}_{1 \mathrm{a}}\right.$ flox/flox]) and expressing Sim1Cre) and littermate control mice ( $\mathrm{AT}_{1 \mathrm{a}}$ flox/flox) were used for all studies and were 10-12 weeks old at the time experiments began. To generate litters that contained both of these genotypes, the dams were $\mathrm{AT}_{1 \mathrm{a}}$ flox/flox and did not express Sim1Cre, while the sires were $\mathrm{AT}_{1 \mathrm{a}}$ flox/flox and carried one copy of the Sim1Cre transgene. For the electrophysiological experiment conducted in wild-type C57BL/6 mice, mice were obtained from Harlan Laboratories. Mice were fed either standard low-fat rodent chow (CHOW; Harlan Teklad LM-485; 3.1 $\mathrm{kcal} / \mathrm{g} ; \sim 5 \%$ fat) or a high-fat diet (HFD; Research Diets D03082706; $4.54 \mathrm{kcal} / \mathrm{g} ; \sim 40 \% \mathrm{fat}$ ). Unless otherwise noted, food and water were provided ad libitum. All animal procedures were approved by the Institutional Animal Care and Use Committees at the University of Florida and the University of Cincinnati.

Food, water, and $\mathrm{NaCl}$ intake. Food intake was assessed manually every $2-3 \mathrm{~d}$ for the duration of the $31 \mathrm{~d}$ study and is reported as cumulative food intake. Water intake was assessed by weighing the water bottles every 2-3 d during 1 wk of CHOW feeding or HFD feeding and is reported as mean daily water intake. Mice maintained on CHOW or HFD were given access to water and a solution of $500 \mathrm{~mm} \mathrm{NaCl}$ for $3 \mathrm{~d}$, and mean daily $\mathrm{NaCl}$ intake was determined. Mice were maintained on HFD for 4 weeks before assessment of water and $\mathrm{NaCl}$ intake.

Body weight and body composition. Body composition was determined using nuclear magnetic resonance technology (Echo NMR) on unanesthetized mice as previously described (Taicher et al., 2003). Body weight was assessed every $2-3 \mathrm{~d}$ for the duration of the study.

Indirect calorimetry. Energy expenditure during fasting and ad libitum feeding conditions was assessed via indirect calorimetry using the Columbus Instruments CLAMS (AccuScan Instruments) system. Twelveweek-old mice were fed HFD for 4 weeks before the initiation of energy expenditure assessment. At the time of the experiment, mice were 16 weeks of age. Mice were allowed to acclimate to the metabolic cages for $1 \mathrm{~d}$. On the first day of energy expenditure assessment, mice were given ad libitum access to HFD. Subsequently, mice were fasted for $16 \mathrm{~h}$, during which time energy expenditure was continuously monitored. $\mathrm{VO}_{2}$ and $\mathrm{VCO}_{2}$ were normalized to lean body mass. Energy expenditure was determined using the following equation: $3.815 * \mathrm{VO}_{2}+1.232 * \mathrm{VCO}_{2}$ and reported in cal/( $\mathrm{kg}$ lean mass) $/ \mathrm{min}$ (Sarruf et al., 2010). Respiratory quotient (RQ) was determined using the following equation: $\mathrm{RQ}=$ $\mathrm{VCO}_{2} / \mathrm{VO}_{2}$.

Tissue collection. After $32 \mathrm{~d}$ of HFD or CHOW feeding, mice were fasted for $2 \mathrm{~h}$ to ensure minimal variability in energy status. Mice were then killed by conscious decapitation for tissue collection at $1000 \mathrm{~h}(4 \mathrm{~h}$ after the onset of the light phase). Whole brains were removed and flash frozen in dry ice-cooled isopentane. Kidney, adrenal, and pituitary were obtained and flash frozen in dry ice-cooled isopentane for gene expression analysis. Plasma was separated from $600 \mu \mathrm{l}$ of trunk blood collected in $20 \mu \mathrm{l}$ of EDTA (100 mM).

Cardiovascular and activity recording via telemetry. While $\mathrm{AT}_{1 \mathrm{a}}$ flox/ flox mice and PVN AT ${ }_{1 \mathrm{a}} \mathrm{KO}$ were under isoflurane anesthesia, radiotelemetry transmitters (Data Sciences International) were placed into the distal left carotid artery and positioned subcutaneously near the left rear flank region. Following recovery and acclimation for 2 weeks, mice were maintained on CHOW ( $\mathrm{AT}_{1 \mathrm{a}}$ flox/flox, $n=4$; $\mathrm{PVN} \mathrm{AT}_{1 \mathrm{a}} \mathrm{KO}, n=4$ ) or placed on HFD ( $\operatorname{AT}_{1 \mathrm{a}}$ flox/flox, $n=4$; $\left.\mathrm{PVN} \mathrm{AT}_{1 \mathrm{a}} \mathrm{KO}, n=4\right)$ and cardiovascular and activity measurements were continuously recorded for $8 \mathrm{~d}$ or 4 weeks, respectively. Data were obtained at 10 s intervals, which were collapsed into $1 \mathrm{~h}$ means to generate a $24 \mathrm{~h}$ profile for each mouse. These $24 \mathrm{~h}$ profiles were then averaged for each mouse to produce a $24 \mathrm{~h}$ profile representing the $8 \mathrm{~d}$ or 4 weeks on CHOW or HFD, respectively. Finally, these datasets were averaged to generate the $24 \mathrm{~h}$ profiles representing the cardiovascular and activity measurements obtained from $\mathrm{AT}_{1 \mathrm{a}}$ flox/flox and PVN AT ${ }_{1 \mathrm{a}}$ KO mice during maintenance on CHOW or HFD for $8 \mathrm{~d}$ or 4 weeks, respectively.

RNA isolation and cDNA synthesis. RNeasy columns (Qiagen) were used to isolate RNA from the hypothalamus, adrenal, pituitary, and renal cortex. DNase treatment (Qiagen) was performed to minimize genomic DNA contamination of RNA extracts. For hypothalamic gene expression analysis, hypothalami were dissected from flash-frozen brains in the chamber of a cryostat $\left(\right.$ at $\left.-15^{\circ} \mathrm{C}\right)$ on the day of RNA extraction. Brains were placed in a cooled metal brain block and razor blades were used to remove the tissue rostral and caudal to the hypothalamus. This portion of the brain containing the hypothalamus was then placed on the stage of the cryostat and the brain tissue lateral and dorsal to the hypothalamus was removed. The isolated hypothalamus was then submerged in $700 \mu \mathrm{l}$ of RLT buffer from the Qiagen RNeasy kit. RNA extraction and DNase treatment procedures were performed according to the manufacturer's instructions. Subsequently, iScript (Bio-Rad) was used to synthesize cDNA from $1 \mu \mathrm{g}$ of total RNA.

Semiquantitative real-time PCR. Gene expression was assessed in the hypothalamus, kidney, adrenal, and pituitary using semiquantitative real-time PCR. For semiquantitative real-time PCR analysis of agouti-related peptide (AgRP; Mm00475829), pro-opiomelanocortin (POMC; Mm00435874), $\mathrm{AT}_{1 \mathrm{a}}(\mathrm{Mm01166161)}$, single-minded 1 (Sim-1; Mm00441390), renin (Mm02342887), arginine vasopressin (AVP; Mm00437761), corticotrophin-releasing hormone (CRH; Mm1293920), oxytocin (OXT; Mm01329577), tumor necrosis factor $\alpha$ (TNF- $\alpha$; Mm00443260), interleukin-6 (IL-6; Mm00446190), IL-1 $\beta$ (Mm00434228), and a cluster of differentiation molecule 11b (CD11b; Mm00434455) diluted (1:5), cDNA samples were run in duplicate using a 7900HT Fast Real-time PCR system, TaqMan Gene Expression Master Mix and validated TaqMan probes (Applied Biosystems). Expression patterns of genes of interest were normalized to constitutively expressed ribosomal protein L32 (Mm02528467) and relative expression was quantified using the $2^{\Delta \Delta \mathrm{Ct}}$ method.

Analysis of plasma measurements. Plasma glucose was determined using the glucose oxidation method as previously described (de Kloet et al., 2009). Plasma renin activity (PRA) levels were determined using a ${ }^{125} \mathrm{I}$ RIA kit from Diasorin, and corticosterone levels were assessed using a ${ }^{125}$ I RIA kit from MP Biomedicals (Krause et al., 2008; de Kloet et al., 2009). Plasma sodium concentration was determined using a dualchannel flame photometer (Cole-Parmer). Plasma proteins and hematocrit were determined using a refractometer and microcapillary reader, respectively.

Semiquantitative receptor autoradiography. Receptor autoradiography was used to assess the efficacy of Cre-mediated deletion of $\mathrm{AT}_{1 \mathrm{a}}$ from the PVN. Autoradiographic measurement of Ang-II binding to central angiotensin receptors was performed as previously described (Krause et al., 2008, 2011).

In vitro whole-cell recording. Male $\mathrm{AT}_{1 \mathrm{a}}$ flox/flox and $\mathrm{PVN} \mathrm{AT}_{1 \mathrm{a}} \mathrm{KO}$ mice maintained on $\mathrm{CHOW}$ and wild-type $\mathrm{C} 57 \mathrm{BL} / 6$ mice maintained on CHOW or HFD were anesthetized with isoflurane and decapitated using a small-animal guillotine. Their brains were rapidly removed and immersed in ice-cold artificial CSF (ACSF). Coronal sections through the hypothalamus were cut at $300 \mu \mathrm{m}$ using a Pelco Series 3000 Vibratome (Pelco) and immediately submerged in an incubator containing ACSF preheated to $30-35^{\circ} \mathrm{C}$. Following a $30 \mathrm{~min}$ incubation period, slices were allowed to equilibrate to room temperature for an additional $30 \mathrm{~min}$ before use. ACSF for sectioning and incubation contained the following (in mM): $124 \mathrm{NaCl}, 2.5 \mathrm{KCl}, 1.2 \mathrm{NaH}_{2} \mathrm{PO}_{4}, 2.5 \mathrm{MgSO}_{4}, 10$ D-glucose, 1 $\mathrm{CaCl}_{2}$, and $25.9 \mathrm{NaHCO}_{3}$, saturated with $95 \% \mathrm{O}_{2}$ and $5 \% \mathrm{CO}_{2}$. ACSF for recording contained the following (in $\mathrm{mM}$ ): $126 \mathrm{NaCl}, 3 \mathrm{KCl}, 1.2$ $\mathrm{NaH}_{2} \mathrm{PO}_{4}, 1.5 \mathrm{MgSO}_{4}, 11 \mathrm{D}$-glucose, $2.4 \mathrm{CaCl}_{2}$, and $25.9 \mathrm{NaHCO}_{3}$. This solution was saturated with $95 \% \mathrm{O}_{2}$ and $5 \% \mathrm{CO}_{2}$, maintained at $30^{\circ} \mathrm{C}$, 

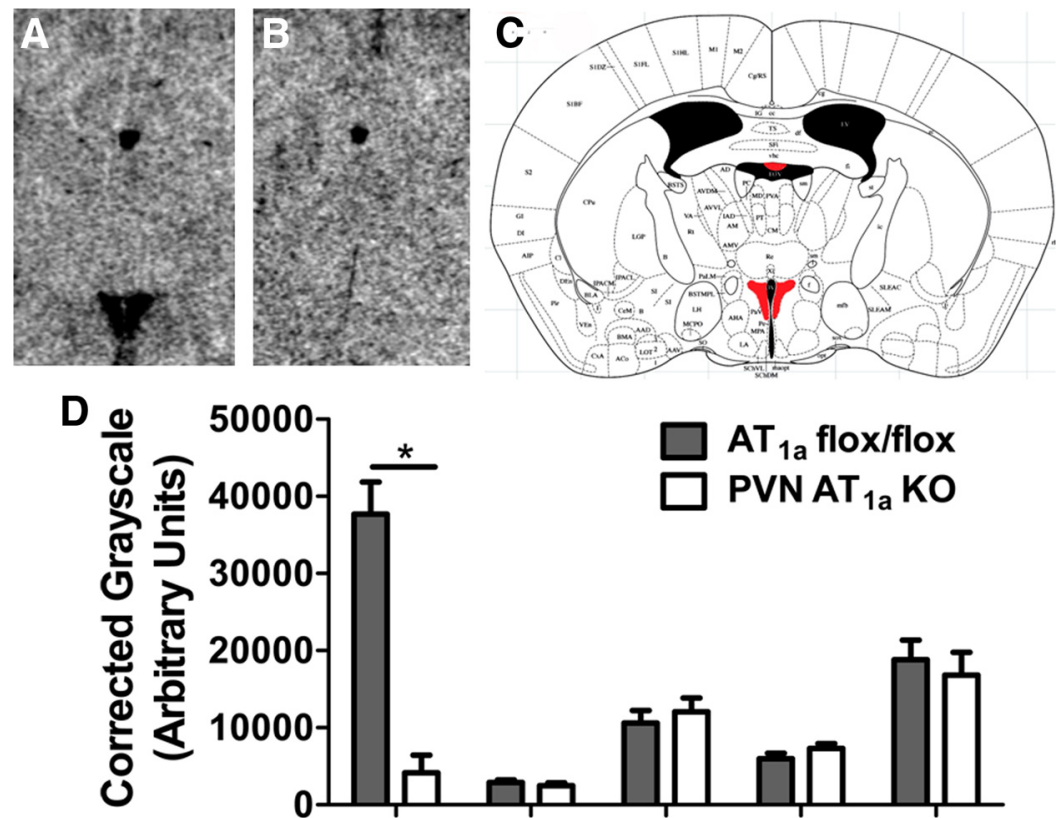

50000

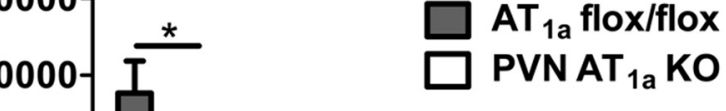
Figure 1. $A T_{1}$ binding in specific brain nuclei. Autoradiographs indicative of Ang-Il binding to $A_{1}$ in a coronal brain section
through the SFO and PVN of the hypothalamus of $A T_{13}$ flox/flox $(\boldsymbol{A})$ and PVN $(\boldsymbol{B}) A T_{1}, K 0$ mice. $C$, Atlas section corresponding to the level of the autoradiographs. $\boldsymbol{D}$, Quantification of Ang-II binding to $\mathrm{AT}_{1}$ in specific brain nuclei. Error bars indicate SEM. $n=$ $8 /$ group; $^{*} p<0.05$.
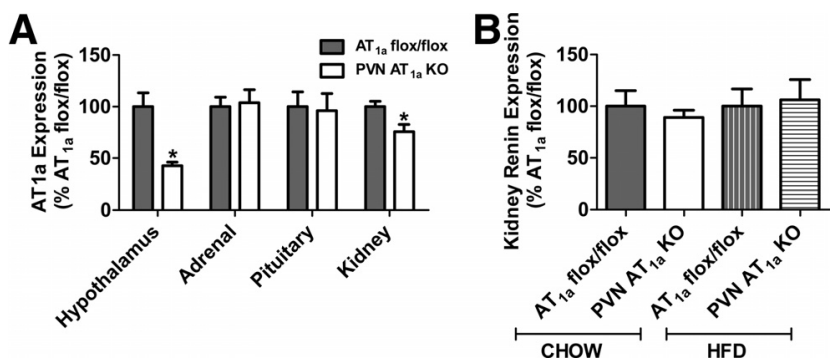

Figure 2. $\quad A_{1 \mathrm{a}}$ and renin gene expression. $A, A T_{1 \mathrm{a}}$ mRNA expression in hypothalamus, adrenal, pituitary, and kidney during $\mathrm{CHOW}$ feeding. $\boldsymbol{B}$, Renin gene expression in kidney during CHOW or HFD feeding. Error bars indicate SEM. $n=7-9 /$ group; ${ }^{*} p<0.05$.

and washed over slices at a rate of $2 \mathrm{ml} / \mathrm{min}$. Whole-cell voltage-clamp recordings were performed using micropipettes pulled from borosilicate glass using a Flaming/Brown electrode puller (Sutter P-97; Sutter Instruments). Electrode tip resistance was between 4 and $6 \mathrm{M} \Omega$ when filled with an internal solution that contained the following (in $\mathrm{mm}$ ): 130 K-gluconate, $10 \mathrm{KCl}, 10 \mathrm{NaCl}, 2 \mathrm{MgCl}_{2}, 1$ EGTA, $2 \mathrm{Na}_{2} \mathrm{ATP}, 0.3 \mathrm{NaGTP}$, and 10 HEPES. This solution was $\mathrm{pH}$ adjusted to 7.3 using $\mathrm{KOH}$ and volume adjusted to 285-300 mOsm. For each cell, $1 \mu \mathrm{M}$ Ang-II was bath applied after $6 \mathrm{~min}$ of stable recording in current-clamp. The initial membrane potential was defined as the mean voltage observed during a continuous $60 \mathrm{~s}$ period extracted from the last $3 \mathrm{~min}$ of baseline recording. The effect of Ang-II was measured in an identical $60 \mathrm{~s}$ window observed between 2 and 5 min after application. The precise timing of these windows was adjusted as necessary to ensure that measurement of the pre-Ang-II or post-Ang-II mean membrane voltage was not contaminated by action potentials.

Statistics. For food intake and body composition studies in HFD- and CHOW-fed, PVN AT $1 \mathrm{a}$ KO and $\mathrm{AT}_{1 \mathrm{a}}$ flox/flox mice, statistical significance was ascertained with two-way ANOVA (genotype and diet as the factors). For endpoints assessed exclusively in CHOW- or HFD-fed mice, including hypothalamic, adrenal, pituitary, and kidney gene expression, plasma measures, water intake, and $\mathrm{NaCl}$ intake, an unpaired Student's $t$ test was used to determine statistical significance. A repeated-measures ANOVA was used for assessment of body mass, energy expenditure, and cardiovascular/activity parameters. In the electrophysiological studies, an unpaired Student's $t$ test was used to compare the mean effect of Ang-II on membrane voltage in the $\mathrm{PVN} \mathrm{AT}_{1 \mathrm{a}} \mathrm{KO}$ mice versus the littermate $\mathrm{AT}_{1 \mathrm{a}}$ flox/flox controls. Basic principles in probability theory were used to test the hypothesis that a higher percentage of cells was responsive to Ang-II in the HFD animals. Statistical significance was set at $p<0.05$ (two-tailed).

\section{Results}

$\mathrm{AT}_{1 \mathrm{a}}$ receptor expression in the brain and peripheral tissues

Coexpression of the Sim1Cre and $\mathrm{AT}_{1 \mathrm{a}}$ flox genes led to reduced $\mathrm{AT}_{1 \mathrm{a}}$ binding within the PVN $\left(t_{(14)}=7.07 ; p<0.05\right)$, but not in other Sim 1 - or $\mathrm{AT}_{1 \mathrm{a}}$-containing brain nuclei, including the supraoptic nucleus (SON, contains Sim1, but not $\mathrm{AT}_{1 \mathrm{a}}$ ), subfornical organ (SFO; contains $\mathrm{AT}_{1 \mathrm{a}}$, but not Sim1), median preoptic nucleus (MnPO; contains $\mathrm{AT}_{1 \mathrm{a}}$ and scattered Sim1) or periventricular nucleus $(\mathrm{PeVN}$; contains $\mathrm{AT}_{1 \mathrm{a}}$, but not Sim1), suggesting that within the brain, $\mathrm{AT}_{1 \mathrm{a}}$ deletion was specific to the PVN (Fig. 1). Coexpression of the Sim1Cre and the $\mathrm{AT}_{1 \mathrm{a}}$ flox transgenes did not affect $\mathrm{AT}_{\mathrm{la}}$ gene expression within the adrenal and pituitary; however, in addition to reduced hypothalamic $\mathrm{AT}_{1 \mathrm{a}}$ gene expression $\left(t_{(15)}=4.82 ; p<0.05\right) \mathrm{PVN} \mathrm{AT}_{1 \mathrm{a}}$ $\mathrm{KO}$ mice had a $\sim 25 \%$ reduction of $\mathrm{AT}_{1 \mathrm{a}}$ levels within the renal cortex $\left(t_{(12)}=2.80 ; p<0.05 ;\right.$ Fig. 2$)$. This reduction in renal $\mathrm{AT}_{1 \mathrm{a}}$ expression is consistent with the scattered Cre expression observed by Balthasar et al. (2005). For detailed discussion of $\mathrm{AT}_{1 \mathrm{a}}$ expression in central and systemic tissues refer to Lenkei et al. (1997), Allen et al. (1999), and Chen et al. (2012).

\section{Sim1Cre and $\mathrm{AT}_{1 \mathrm{a}}$ flox/flox coexpression does not affect kidney function or hydromineral balance}

Due to the slight decrease in kidney $\mathrm{AT}_{1 \mathrm{a}}$, it was necessary to assess the impact of the genetic manipulation on kidney function. Thus, indices of both kidney function and hydromineral balance were assessed in $\mathrm{AT}_{1 \mathrm{a}}$ flox/flox and $\mathrm{PVN} \mathrm{AT}_{1 \mathrm{a}} \mathrm{KO}$ mice fed CHOW or HFD for 4 weeks. PVN AT 1 deletion did not alter hematocrit, plasma protein, plasma $\mathrm{Na}^{+}$, glucose, CORT, or ACTH levels when mice were maintained on CHOW or HFD (Table 1). Furthermore, PRA (Table 1) and kidney renin mRNA (Fig. 2) expression were not different between the $\mathrm{AT}_{1 \mathrm{a}}$ flox/flox and PVN $\mathrm{AT}_{1 \mathrm{a}} \mathrm{KO}$ mice maintained on $\mathrm{CHOW}$ or HFD. Water $(4.52 \pm 0.33 \mathrm{ml} / \mathrm{d}$ vs $4.87 \pm 0.19 \mathrm{ml} / \mathrm{d}$ when maintained on CHOW; $n=8-9 /$ group; $2.38 \pm 0.20 \mathrm{ml} / \mathrm{d}$ vs $2.34 \pm 0.11 \mathrm{ml} / \mathrm{d}$ when maintained on HFD; $n=5-6 /$ group) and $500 \mathrm{~mm} \mathrm{NaCl}(0.57 \pm 0.06 \mathrm{ml} / \mathrm{d}$ vs $0.58 \pm 0.08 \mathrm{ml} / \mathrm{d}$ when maintained on CHOW; $n=8-9 /$ group; $1.05 \pm 0.15 \mathrm{ml} / \mathrm{d}$ vs $1.05 \pm 0.14 \mathrm{ml} / \mathrm{d}$ when maintained on HFD; $n=5-6 /$ group) intake were also not different between the groups. Collectively, these data suggest that PVN AT $\mathrm{Pa}_{1 \mathrm{a}} \mathrm{KO}$ mice do not have altered kidney function or hydromineral imbalance when maintained on CHOW or HFD. 
Table 1. Baseline plasma measurements obtained from control AT ${ }_{1 a}$ flox/flox and PVN AT1 $\mathrm{a}$ KO mice fed CHOW or HFD

\begin{tabular}{|c|c|c|c|c|}
\hline & \multicolumn{2}{|l|}{$\mathrm{AT}_{1 \mathrm{a}}$ flox/flox } & \multicolumn{2}{|l|}{$\mathrm{PVN} \mathrm{AT}_{1 \mathrm{a}} \mathrm{KO}$} \\
\hline & $\mathrm{CHOW}$ & HFD & CHOW & HFD \\
\hline Hematocrit (\%) & $45.8 \pm 1.0(n=5)$ & $46.1 \pm 0.5(n=5)$ & $44.6 \pm 0.6(n=7)$ & $44.6 \pm 0.6(n=7)$ \\
\hline Plasma protein (g/dl) & $5.6 \pm 0.2(n=5)$ & $5.38 \pm 0.1(n=5)$ & $5.3 \pm 0.1(n=7)$ & $5.3 \pm 0.1(n=7)$ \\
\hline Plasma sodium (mм) & $149.1 \pm 4.0(n=5)$ & $143.9 \pm 1.1(n=5)$ & $143.3 \pm 1.0(n=7)$ & $144.0 \pm 1.7(n=7)$ \\
\hline PRA (Ang-I ng/ml/h) & $26.8 \pm 4.3(n=7)$ & $19.1 \pm 6.6(n=5)$ & $21.5 \pm 5.4(n=7)$ & $25.6 \pm 5.3(n=7)$ \\
\hline CORT (ng/ml) & $10.5 \pm 1.5(n=9)$ & $15.5 \pm 2.3(n=9)$ & $12.6 \pm 2.8(n=8)$ & $13.0 \pm 2.3(n=9)$ \\
\hline ACTH (pg/ml) & $16.4 \pm 3.3(n=8)$ & $15.1 \pm 4.5(n=8)$ & $13.7 \pm 3.2(n=7)$ & $12.2 \pm 3.1(n=8)$ \\
\hline Glucose (mg/dl) & $146.6 \pm 5.5(n=9)$ & $153.2 \pm 9.0(n=9)$ & $145.1 \pm 8.0(n=8)$ & $152.4 \pm 6.3(n=9)$ \\
\hline
\end{tabular}

PVN AT $_{1 \text { a }}$ deletion enhances

susceptibility to diet-induced body and adipose mass gain

At 10-12 weeks of age, $\mathrm{AT}_{1 \mathrm{a}}$ flox/flox and PVN AT 1 a KO mice were body mass matched and subdivided into $\mathrm{CHOW}$ and HFD-fed groups. At the initiation of the study, $\mathrm{AT}_{1 \mathrm{a}}$ flox/flox and PVN $\mathrm{AT}_{1 \mathrm{a}} \mathrm{KO}$ mice had similar body masses $(29.00 \pm 0.57 \mathrm{~g}$ vs $29.37 \pm 0.63 \mathrm{~g}) . \mathrm{AT}_{1 \mathrm{a}}$ flox/flox and PVN AT 1 KO mice maintained on $\mathrm{CHOW}$, gained similar amounts of body mass, adipose mass, and lean mass, regardless of genotype (Fig. 3). When given an HFD, both $\mathrm{AT}_{1 \mathrm{a}}$ flox/flox and PVN $\mathrm{AT}_{1 \mathrm{a}} \mathrm{KO}$ mice gained significantly more body mass and adipose mass than CHOW-fed mice (Fig. 3; main effect of diet; $\left.F_{(1,29)}=5.67 ; p<0.05\right)$. Starting on day 9, however, PVN $\mathrm{AT}_{1 \mathrm{a}} \mathrm{KO}$ mice given HFD gained significantly more body mass than $\mathrm{AT}_{1 \mathrm{a}}$ flox/flox mice given HFD (gene $\times$ diet interaction; $F_{(1,29)}=$ 9.52; $p<0.01$ ). This difference in body mass is mostly attributable to an increase in adiposity, since after $28 \mathrm{~d}$ of HFD feeding, $\mathrm{PVN} \mathrm{AT}_{1 \mathrm{a}} \mathrm{KO}$ mice gained $\sim 3$ g more adipose mass than did $\mathrm{AT}_{1 \mathrm{a}}$ flox/flox mice (gene $\times$ diet interaction; $F_{(1,29)}=6.86$; $p<0.05)$. There was no effect of genotype on lean mass although there was a main effect of diet on lean mass $\left(F_{(1,29)}=14.10\right.$; $p<0.001)$.

\section{PVN AT ${ }_{1 \mathrm{a}}$ deletion increases energy consumption and} reduces energy expenditure in HFD-fed mice

Throughout the study, food intake and energy expenditure were assessed as potential mechanisms for the reduced body mass. When mice were maintained on CHOW, PVN AT $_{1 \mathrm{a}}$ deletion had no effect on food intake. Conversely, $\mathrm{PVN} \mathrm{AT}_{1 \mathrm{a}} \mathrm{KO}$ mice exhibited increased consumption of $\mathrm{HFD}$, relative to $\mathrm{AT}_{1 \mathrm{a}}$ flox/flox mice maintained on HFD (Fig. 4; gene $\times$ diet interaction; $F_{(1,27)}=$ 8.50; $p<0.001)$. Energy expenditure during fasting and ad libitum feeding was assessed in $\mathrm{AT}_{1 \mathrm{a}}$ flox/flox and PVN $\mathrm{AT}_{1 \mathrm{a}} \mathrm{KO}$ mice maintained on HFD for 4 weeks (Fig. 4). As depicted in Figure 4, $\mathrm{PVN} \mathrm{AT}_{1 \mathrm{a}}$ deletion resulted in a significant reduction in energy expenditure regardless of whether the mice were fasting or ad libitum feeding (main effect of genotype during fasting: $F_{(1,14)}=13.66 ; p<0.01$ and ad libitum feeding: $F_{(1,14)}=13.66$; $p<0.01)$. Additionally, there was a significant effect of genotype on RQ during ad libitum-feeding $\left(F_{(1,14)}=4.81 ; p<0.05\right)$. In general, the PVN AT $1 \mathrm{a}$ KO mice had an elevated RQ relative to
$\mathrm{AT}_{1 \mathrm{a}}$ flox/flox mice, suggestive of a reduced utilization of fat (enhanced utilization of carbohydrates) in the PVN AT $1 \mathrm{a}$ KO mice. Conversely, during the fast, there was no significant effect of genotype on RQ, although it did significantly change over time $\left(F_{(26,364)}=15.56 ; p<0.001\right)$ from an initial level of $\sim 0.79$ to a fasting level of $\sim 0.71$. These data indicate that both genotypes shifted to a greater utilization of fat during the fast.

PVN AT $_{1 \mathrm{a}}$ deletion reduces blood pressure and activity during HFD feeding

Cardiovascular parameters were assessed in $\mathrm{AT}_{1 \mathrm{a}}$ flox/flox and $\mathrm{PVN} \mathrm{AT}_{1 \mathrm{a}} \mathrm{KO}$ mice maintained on CHOW or HFD for $8 \mathrm{~d}$ or 4 weeks, respectively (Fig. 5). As expected, in the $\mathrm{CHOW}$ condition there was an effect of time on systolic blood pressure $\left(F_{(23,138)}=\right.$ $31.9 ; p<0.001)$, heart rate $\left(F_{(23,138)}=35.16 ; p<0.001\right)$, and activity $\left(F_{(23,138)}=10.21 ; p<0.001\right)$ with larger values occurring during the dark phase. There was no effect of genotype with $\mathrm{AT}_{1 \mathrm{a}}$ flox/flox and PVN $\mathrm{AT}_{1 \mathrm{a}} \mathrm{KO}$ mice having similar systolic blood pressure, heart rate, and activity when given $\mathrm{CHOW}$ (Fig. 5A-C). 


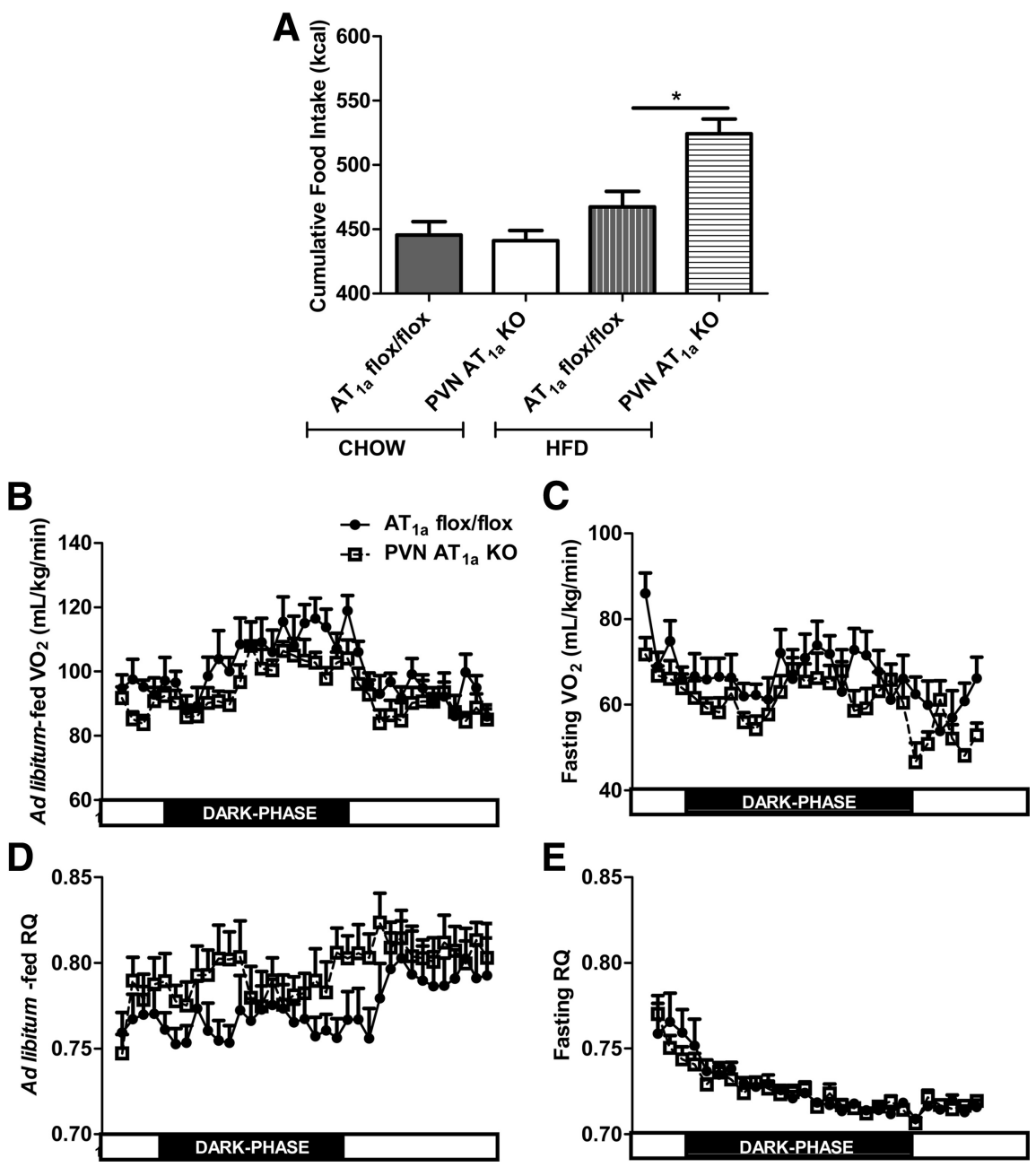

Figure 4. $\mathrm{PVN} \mathrm{AT}_{1 \mathrm{a}}$ deletion increases energy consumption and reduces energy expenditure in HFD-fed mice. $\boldsymbol{A}$, Cumulative $31 \mathrm{~d}$ food intake of $\mathrm{AT}_{1 \mathrm{a}}$ flox/flox and $\mathrm{PVN} \mathrm{AT}_{1 \mathrm{a}} \mathrm{KO}$ mice fed CHOW or HFD. B, Ad libitum feeding and fasting energy expenditure (C) relative to lean mass in $\mathrm{AT}_{1 \mathrm{a}}$ flox/flox and PVN $\mathrm{AT}_{1 \mathrm{a}} \mathrm{KO}$ mice fed HFD. $\boldsymbol{D}$, Ad libitum-feeding and fasting $\mathrm{RQ}(\boldsymbol{E}) \mathrm{AT}_{1 \mathrm{a}}$ flox/flox and PVN $\mathrm{AT}_{1 \mathrm{a}} \mathrm{KO}$ mice fed CHOW or HFD. Error bars indicate SEM. $n=7-9 /$ group; ${ }^{*} p<0.05$.

However, maintenance on HFD revealed a genotype by time interaction, with $\mathrm{PVN} \mathrm{AT}_{1 \mathrm{a}} \mathrm{KO}$ mice having reduced systolic blood pressure $\left(F_{(23,138)}=1.92 ; p<0.05\right)$ and activity $\left(F_{(23,138)}=2.41\right.$; $p<0.001)$ during the dark phase relative to $\mathrm{AT}_{1 \mathrm{a}}$ flox/flox mice (Fig. $5 D, F)$. Heart rate, on the other hand, was not affected by genotype, although there was a main effect of time $\left(F_{(23,138)}=\right.$ 38.75; $p<0.001$; Fig. 5E).

PVN AT $_{1 \mathrm{a}}$ deletion modulates hypothalamic gene expression To explore some potential mechanisms downstream of $\mathrm{AT}_{1 \mathrm{a}}$ for Ang-II's energy balance regulatory functions, hypothalamic gene expression was assessed in $\mathrm{AT}_{1 \mathrm{a}}$ flox/flox and PVN AT $\mathrm{P}_{1 \mathrm{a}} \mathrm{KO}$ mice maintained on HFD (Fig. 6). Mice lacking the $\mathrm{AT}_{1 \mathrm{a}}$ receptor specifically in the PVN have reduced expression of CRH $\left(t_{(15)}=\right.$ $2.30 ; p<0.05)$ and OXT $\left(t_{(15)}=2.19 ; p<0.05\right)$ mRNAs; however AVP mRNA expression was not different between the genotypes. Additionally, the hypothalamic arcuate nucleus (ARC)-specific genes, AgRP and POMC were not altered in mice lacking $\mathrm{AT}_{1 \mathrm{a}}$ in the PVN. During HFD feeding, PVN AT Pa $_{\text {a }}$ deletion also causes a significant reduction in gene expression for TNF- $\alpha\left(t_{(15)}=2.81 ; p<\right.$ $0.05)$, a pro-inflammatory cytokine, and CD11b $\left(t_{(15)}=2.49\right.$; $p<0.05)$, a marker for active microglia.
PVN AT $_{1 \mathrm{a}}$ deletion eliminates the response of parvocellular neurons in the PVN to bath-applied Ang-II

We used whole-cell recording techniques (see Materials and Methods) to examine the effects of bath-applied Ang-II on PVN parvocellular neurons in both $\mathrm{AT}_{1 \mathrm{a}}$ flox/ flox and PVN $\mathrm{AT}_{1 \mathrm{a}} \mathrm{KO}$ mice. In both groups parvocellular neurons had high input resistance $\left(\mathrm{AT}_{1 \mathrm{a}}\right.$ flox/flox: $842 \pm 158$ $\mathrm{M} \Omega, \mathrm{PVN} \mathrm{AT}_{1 \mathrm{a}} \mathrm{KO}: 814 \pm 104 \mathrm{M} \Omega$ ) and low capacitance $\left(\mathrm{AT}_{1 \mathrm{a}}\right.$ flox/flox: $7.7 \pm 1.3$ $\left.\mathrm{pF}, \mathrm{PVN} \mathrm{AT}_{1 \mathrm{a}} \mathrm{KO}: 11 \pm 1.8 \mathrm{pF}\right)$ as assessed with brief $(25 \mathrm{~ms})$ voltage steps from -70 to $-80 \mathrm{mV}$ in voltage-clamp mode. Similarly, in both groups some parvocellular neurons exhibited intrinsic electrophysiological properties suggestive of pre-autonomic neurons, while other neurons were likely neurosecretory. For more information on how intrinsic properties were used to select cells see Figure 7A-C (Hoffman et al., 1991; Tasker and Dudek, 1991; Stern, 2001; Luther et al., 2002). We focused on parvocellular populations, due to their known role in regulation of body weight. To test the effects of bath application of Ang-II, the membrane potential was adjusted in current-clamp mode to near $-60 \mathrm{mV}$ (AT $1 \mathrm{a}$ flox/flox: $-63 \pm 2.4 \mathrm{mV}, \mathrm{PVN} \mathrm{AT}_{1 \mathrm{a}}$ $\mathrm{KO}:-61 \pm 1.7 \mathrm{mV}$ ) using mild holding currents $\left(\mathrm{AT}_{1 \mathrm{a}}\right.$ flox/flox: $-31 \pm 11 \mathrm{pA}, \mathrm{PVN}$ $\mathrm{AT}_{1 \mathrm{a}} \mathrm{KO}:-0.5 \pm 8.5 \mathrm{pA}, t_{(18)}=2.3 ; p=$ 0.04 ). Consistent with prior reports (Li et al., 2003; Cato and Toney, 2005; Latchford and Ferguson, 2005) bath application of $1 \mu \mathrm{M}$ Ang-II in the control group produced a clear depolarization in 6 of 10 cells tested (overall mean depolarization: $8.4 \pm 2.7 \mathrm{mV}, t_{(9)}=$ 3.10; $p=0.01$, responders only: $14 \pm 2.7$ $\left.\mathrm{mV}, t_{(5)}=5.12 ; p=0.004\right)$. In sharp contrast, this effect was eliminated in PVN AT $1 \mathrm{a}$ KO mice (mean depolarization: $1.6 \pm 0.6 \mathrm{mV}$, $t_{(18)}=3.64 ; p=0.002$ vs all controls, $t_{(14)}=5.6 ; p<0.0001 \mathrm{vs}$ control responders). These results indicate that $\mathrm{PVN}$-specific $\mathrm{AT}_{1 \mathrm{a}}$ deletion effectively removes the physiological response of PVN parvocellular neurons to acute application of Ang-II.

HFD-induced obesity increases the percentage of PVN parvocellular neurons that are responsive to Ang-II In a final series of experiments, we used electrophysiological techniques to examine the effects of bath-applied Ang-II on PVN parvocellular neurons in wild-type C57BL/6 mice maintained on CHOW or HFD (see Materials and Methods). Parvocellular neurons were selected as in prior experiments. Input resistance and whole-cell capacitance were not affected by diet, and were similar to those observed in $\mathrm{AT}_{1 \mathrm{a}}$ flox/flox and PVN AT $\mathrm{Pa}_{1 \mathrm{a}} \mathrm{KO}$ mice $(\mathrm{Rm}$ CHOW: $742 \pm 80.4 \mathrm{M} \Omega$, HFD: $804 \pm 79.7 \mathrm{M} \Omega$; Cm CHOW: $9.2 \pm 1.0 \mathrm{pF}$, HFD: $10.8 \pm 1.24 \mathrm{pF}$ ). Overall, our results indicate that maintenance on the HFD led to a significant increase in body weight (CHOW: $24.3 \pm 0.38 \mathrm{~g}$, HFD: $30.1 \pm 1.21 \mathrm{~g}, t_{(23)}=4.1$; $p<0.001$ ), but across all cells tested, did not produce a statistically significant increase in the mean depolarization produced by 

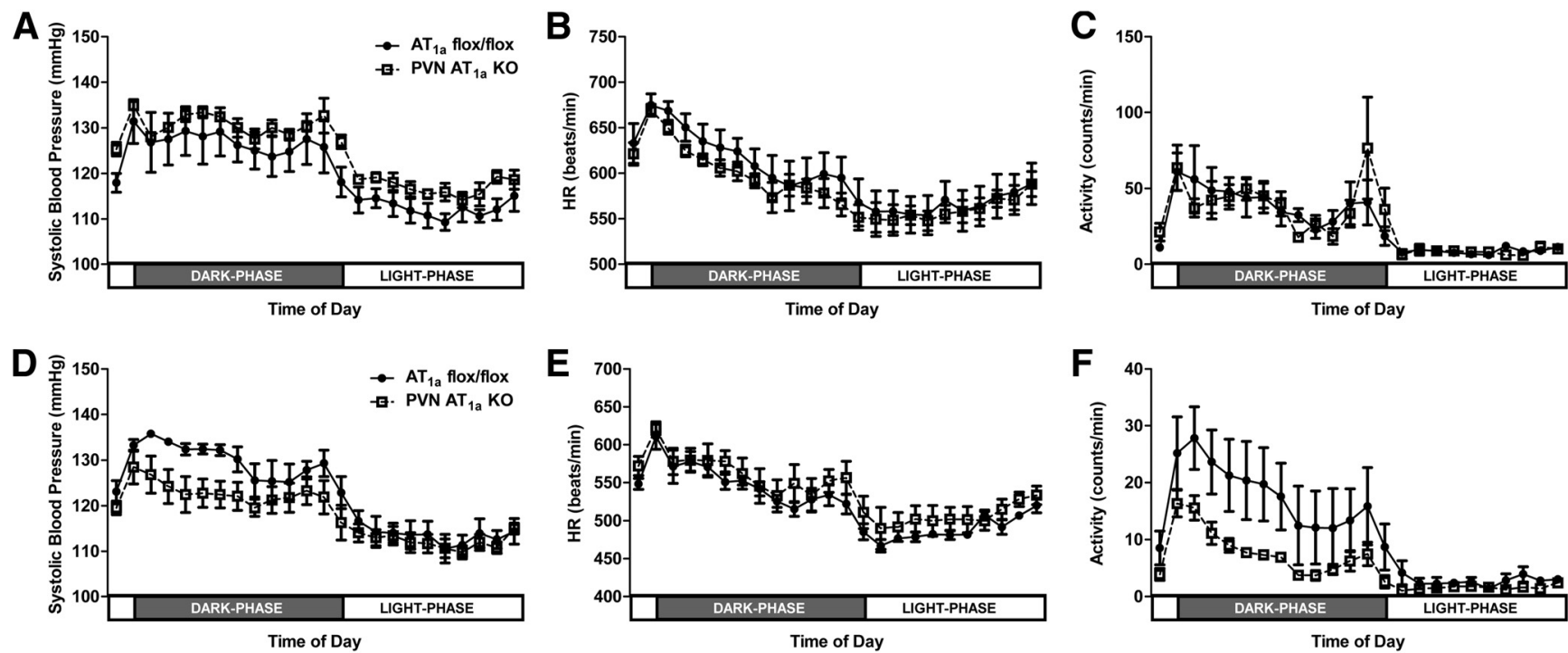

Figure 5. $\mathrm{PVN} \mathrm{AT}_{1 \mathrm{a}}$ deletion reduces blood pressure and activity during HFD feeding. $\boldsymbol{A}$, Systolic blood pressure, heart rate $(\mathrm{HR} ; \boldsymbol{B})$, and activity $(\boldsymbol{C})$ of $\mathrm{AT}_{1 \mathrm{a}}$ flox/flox and PVN AT ${ }_{1 \mathrm{a}} \mathrm{KO}$ mice during $8 \mathrm{~d}$ of $\mathrm{CHOW}$ feeding. $\boldsymbol{D}$, Systolic blood pressure, HR $(\boldsymbol{E})$, and activity $(\boldsymbol{F})$ of $\mathrm{AT}_{1 \mathrm{a}}$ flox/flox and PVN AT ${ }_{1 \mathrm{a}}$ KO mice during 4 weeks of HFD feeding. Error bars indicate SEM. $n=4 / \mathrm{group}$.

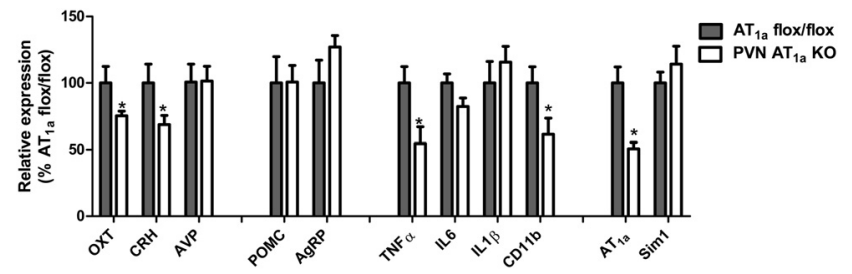

Figure 6. $\mathrm{PVNAT}_{1 \mathrm{a}}$ deletion modulates hypothalamic gene expression. Hypothalamic expression of AgRP, POMC, AT ${ }_{1 \mathrm{a}}$, Sim-1, AVP, CRH, OXT, TNF- $\alpha$, IL-6, IL-1 $\beta$, and CD11b in AT ${ }_{1 \mathrm{a}}$ flox/ flox and PVN $\mathrm{AT}_{1 \mathrm{a}} \mathrm{KO}$ mice fed HFD for $31 \mathrm{~d}$. Data were normalized to the constitutively expressed ribosomal protein $\mathrm{L} 32$ and expressed as percentage $\mathrm{AT}_{1 \mathrm{a}}$ flox/flox. Error bars indicate SEM. $n=8-9 /$ group; ${ }^{*} p<0.05$.

Ang-II (CHOW: $2.4 \pm 1.3 \mathrm{mV}$; HFD: $3.6 \pm 1.0 \mathrm{mV}$ ). However, this is not an optimal analysis because some parvocellular neurons lacked $\mathrm{AT}_{1 \mathrm{a}}$ and some mice were resistant to diet-induced obesity. Further, it is possible that the primary effect of the HFD is on the percentage of cells responsive to Ang-II rather than the extent to which individual cells are depolarized. To test this hypothesis, we defined a responsive cell as one in which bath application of Ang-II depolarized the membrane potential by an amount that was $\geq 2$ times the SE observed across all cells tested in the CHOW group. This test was applied to all cells tested in both $\mathrm{CHOW}$ and HFD groups. Similarly, we then defined an HFD (obese) animal as one whose body weight was $\geq 95 \%$ confidence interval for mean body weight observed in the CHOW group (e.g., $\geq \mathrm{CHOW}$ mean weight $+\left[2^{\star} \mathrm{SD}\right.$ of the mean $]$ ), while an HFD (lean) animal was one maintained on HFD whose body weight did not meet that standard. With these definitions in place, it became clear that the probability of observing a response to Ang-II was indeed significantly increased in the HFD (obese) population (from 4/11 [36.4\%] in CHOW to 8/9 [88.9\%], $p=$ $0.002)$, but was unaltered in the HFD (lean) population $(2 / 5$ [40\%]; Fig. 8).

\section{Discussion}

The present data highlight an environment and gene interaction whereby increased fat intake augments PVN AT ${ }_{1 a}$ activation to alleviate weight gain. PVN AT ${ }_{1 \mathrm{a}} \mathrm{KO}$ mice had an enhanced sus- ceptibility to HFD-induced body and adipose mass gain. The increased body weight and adiposity of PVN AT $\mathrm{Pa}_{1 \mathrm{a}} \mathrm{KO}$ mice fed HFD was the result of increased food intake and decreased energy expenditure. Measures of hypothalamic gene expression in conjunction with electrophysiological studies suggest that PVN AT mediate hypothalamic inflammation, which in turn may influence the activation of PVN neurons that express CRH or OXT to regulate energy intake and expenditure. Together, these studies underscore an important role for $\mathrm{PVN} \mathrm{AT}_{1 \mathrm{a}}$ in the regulation of energy balance during HFD-induced obesity, a condition that increases RAS activity (Boustany et al., 2004; Rahmouni et al., 2004).

In the brain, mice homozygous for the $\mathrm{AT}_{1 \mathrm{a}}$ flox gene that express Cre-recombinase under control of the Sim 1 promoter exhibit PVN-selective deletion of $\mathrm{AT}_{1 \mathrm{a}}$. In peripheral tissues, $\mathrm{AT}_{1 \mathrm{a}}$ expression in adrenal and pituitary was not different between $\mathrm{AT}_{1 \mathrm{a}}$ flox/flox and PVN AT $1 \mathrm{a} \mathrm{KO}$ mice; however, PVN $\mathrm{AT}_{1 \mathrm{a}} \mathrm{KO}$ mice had a slight reduction of renal cortex $\mathrm{AT}_{1 \mathrm{a}}$ expression. Despite this reduction, there were no differences in indices of renal function. Moreover, PRA and kidney renin gene expression were not different between the groups, suggesting that $\mathrm{AT}_{1 \mathrm{a}}$ deletion from Sim1-containing cells does not affect systemic RAS activity.

Our study reveals that deletion of $\mathrm{AT}_{1 \mathrm{a}}$ from the PVN exacerbates diet-induced body and adipose mass gain, findings that are consistent with reports suggesting a role for Ang-II in the regulation of energy balance (Furuhashi et al., 2004; Porter and Potratz, 2004; Grobe et al., 2010; Yamamoto et al., 2011; de Kloet et al., 2011b). Elevations in central Ang-II either via exogenous administration or transgenically via the coexpression of human renin and angiotensinogen reduces body weight and adiposity (Porter et al., 2003; Furuhashi et al., 2004; Grobe et al., 2010; de Kloet et al., 2011b), supporting the hypothesis that high, perhaps supraphysiological, levels of Ang-II are sufficient to reduce adiposity. These previous studies, however, did not address the necessity of Ang-II in energy balance regulation during physiological conditions that elevate RAS activity. To this end, the necessity of the RAS in the regulation of energy balance has been investigated by targeting RAS components throughout the entire body. These nonselective manipulations cannot reveal the central mecha- 

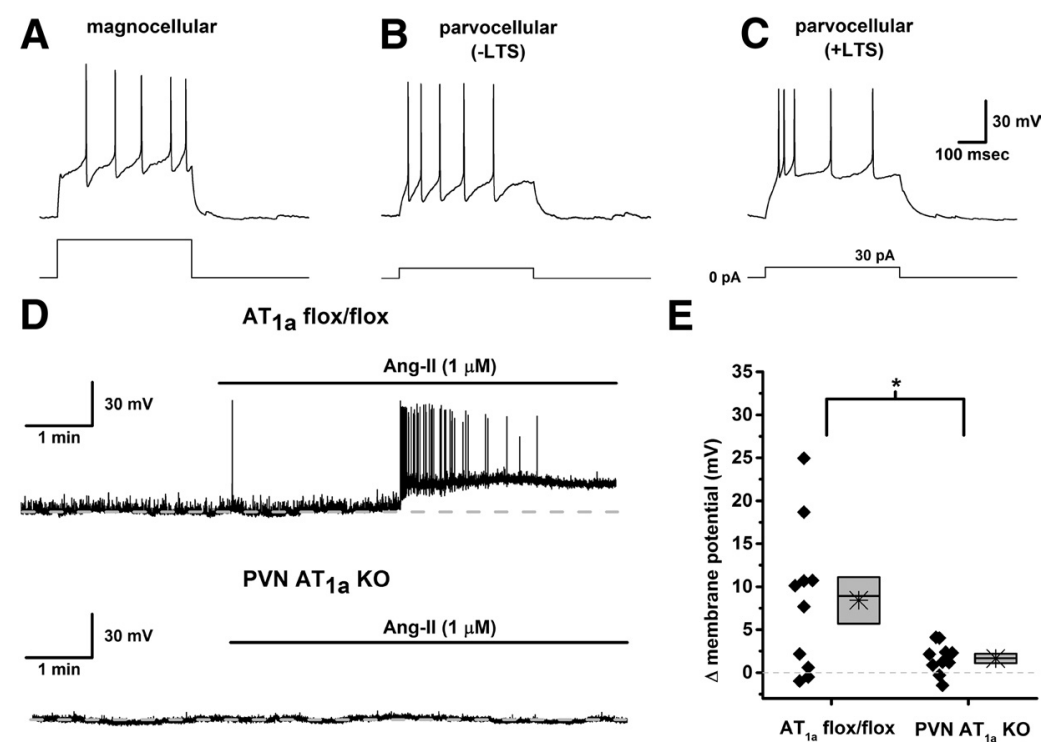

Figure 7. $\mathrm{PVN} \mathrm{AT}_{1 \mathrm{a}}$ deletion eliminates the response of parvocellular neurons in the PVN to bath-applied Ang-II. $\boldsymbol{A}$, Illustrates the response of a typical magnocellular neuron in the PVN to a maintained current injection (here $110 \mathrm{pA}$ by $500 \mathrm{~ms}$, square pulse) in current-clamp. These neurons could be identified by expression of a characteristic transient outwardly rectifying potassium conductance (IA) that produces a notable increase in the time to the first action potential as observed during a maintained depolarization. These types of neurons were avoided in our study. The remaining parvocellular neurons had high input resistance and low capacitance (see Results), lacked IA, and varied in the extent to which they displayed a low-threshold spike (LTS; often associated with pre-autonomic neurons). $\boldsymbol{B}$, Illustrates the response of a typical parvocellular neuron that lacks an LTS, while $\boldsymbol{C}$ illustrates the response of a neuron with a more obvious LTS, which contributes to several rapid action potentials near the onset of the current step. The square pulse in $\boldsymbol{A}-\boldsymbol{C}$ indicates the time of direct current injection into the soma via the recording pipette, 500 ms by $110 \mathrm{pA}$ in $\boldsymbol{A}$, and $500 \mathrm{~ms}$ by $30 \mathrm{pA}$ in $\boldsymbol{B}$ and $\boldsymbol{C}$. $\boldsymbol{D}$, Top, Raw data from an individual experiment indicating a robust response to bath-applied Ang-II in a parvocellular neuron from a control animal. $\boldsymbol{D}$, Bottom, An identical experiment indicating a typical lack of response to bath-applied Ang-II in a parvocellular neuron from a PVN AT ${ }_{1 \mathrm{a}} \mathrm{KO}$ animal. Dotted line in $\boldsymbol{D}$ indicates the resting membrane potential. $\boldsymbol{E}$, Summary data from both datasets. For each dataset, black diamonds indicate the change in membrane potential observed in response to bath application of Ang-II. The large asterisks in each box indicates the population mean, the box size indicates the SE above and below the mean, while the horizontal line across the box indicates the median. Small asterisk (top, center) indicates a significant difference in the overall population mean $\left(t_{(18)}=3.6, p=0.02\right.$; see Results). $\mathrm{AT}_{1 \mathrm{a}}$ flox/flox: $n$ (cells) $=10, n$ (animals) $=7 ;$ PVN AT $_{1 \mathrm{~d}} \mathrm{KO}: n$ (cells) $=10, n$ (animals) $=5$.

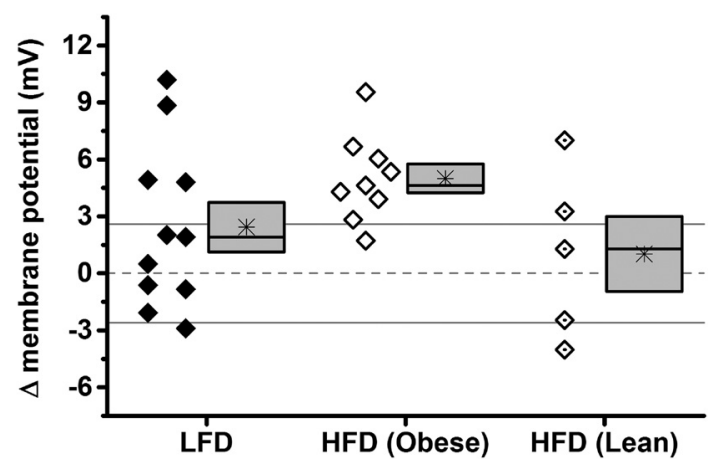

Figure 8. HFD-induced obesity increases the percentage of PVN parvocellular neurons that are responsive to Ang-II. Box plots illustrate the effect of bath-applied Ang-ll on membrane potential of PVN parvocellularneurons in CHOW, HFD (obese), and HFD (lean) groups (see Results). For each group, the effect of Ang-ll on each cell tested is illustrated on the left (diamonds), while information about the population is illustrated with the box on the right. Specifically, the line across each box represents the population median, the asterisks in each box illustrate the population mean, and the size of each box indicates the SEM. The dotted gray line indicates no effect, while the solid gray lines indicate no effect \pm two times the SE of the population mean from the CHOW group. A cell was considered responsive to Ang-ll if the change in membrane potential produced by Ang-ll exceeded the top gray line. Overall, when compared with the CHOW group, the probability of being responsive to Ang-ll was significantly higher in the HFD (obese) group, but not in the HFD (lean) group (see Results). CHOW: $n$ (cells) $=11, n$ (animals) $=7$. HFD total: $n$ (cells) $=14, n$ (animals) $=6$. HFD (obese) $: n$ (cells) $=9$, $n$ (animals) $=4$. HFD (lean) $n$ (cells) $=5, n$ (animals) $=2$. nism(s) of the influence of Ang-II on metabolic regulation and have produced phenotypes that often contrast the obesity produced by selective deletion of PVN AT $\mathrm{T}_{1 \mathrm{a}}$. Rodents given pharmacological RAS inhibitors (Weisinger et al., 2008; de Kloet et al., 2009) and mice lacking angiotensinogen (Massiera et al., 2001), angiotensinconverting enzyme (Jayasooriya et al., 2008), renin (Takahashi et al., 2007), or angiotensin receptors (Kouyama et al., 2005; Yvan-Charvet et al., 2005) are lean, consistent with a role of the systemic RAS in promoting energy storage. The divergence between the central and peripheral effects of the RAS suggests the presence of a negative feedback pathway that is activated when adipose angiotensinogen levels are high, allowing adipose-derived Ang-II to access the brain and provide a brake on peripheral Ang-II action. The present data indicate that PVN $\mathrm{AT}_{1 \mathrm{a}}$ may coordinate this negative feedback.

The increased adiposity of PVN AT 1 a $\mathrm{KO}$ mice was the result of increased food intake and decreased energy expenditure. Although CHOW intake was not altered by PVN $\mathrm{AT}_{1 \mathrm{a}}$ deletion, these mice consumed more HFD, suggesting that PVN $\mathrm{AT}_{1 a}$ regulate food intake during HFD feeding (an environmental manipulation that increases RAS activity; Boustany et al., 2004). Moreover, when fed HFD, these mice exhibited reduced energy expenditure, activity, and blood pressure. These results are consistent with previous findings that central administration of Ang-II produces anorexia and elevates energy expenditure (Porter and Potratz, 2004; Grobe et al., 2010; de Kloet et al., 2011b), while transgenically reducing brain RAS activity via the brain expression of antisense oligonucleotides targeting angiotensinogen, elevates food intake (Kasper et al., 2005). Mice with whole-body deficits in RAS components can be lean or obese; however, in both cases they are hyperphagic (Kouyama et al., 2005; Yamamoto et al., 2011), consistent with a central role of the RAS in reducing food intake.

The reduced energy expenditure observed in our studies was associated with elevated RQ, representing a shift in caloric utilization from fat to carbohydrates. This shift likely contributes to the increased adiposity of PVN $\mathrm{AT}_{1 \mathrm{a}} \mathrm{KO}$ mice maintained on HFD and indicates that the PVN AT $1 \mathrm{a}$ may regulate fat deposition. White and brown adipose tissue depots are innervated by the sympathetic nervous system and parvocellular $\mathrm{AT}_{1 \mathrm{a}^{-}}$ expressing PVN neurons regulate sympathetic outflow. Administration of Ang-II increases the expression of indices of sympathetic activation of adipose tissue, which may increase lipolysis (Porter and Potratz, 2004; de Kloet et al., 2011b). The present data, in conjunction with these previous studies, suggest that Ang-II regulates energy expenditure via sympathetic activation of adipose tissue.

It can be inferred from these studies that Ang-II regulates energy expenditure during HFD feeding by controlling blood pressure and activity. Despite increased adiposity of HFD-fed 
PVN AT ${ }_{1 a}$ KO mice, blood pressure and activity were reduced relative to HFD-fed $\mathrm{AT}_{1 \mathrm{a}}$ flox/flox controls. These data suggest a key role for $\mathrm{PVN} \mathrm{AT}_{1 \mathrm{a}}$ in blood pressure regulation subsequent to the increased RAS activity that occurs during HFD-induced obesity, and are consistent with studies implicating $\mathrm{PVN} \mathrm{AT}_{1 \mathrm{a}}$ in sympathetic nervous system regulation (Li et al., 1996; Zhu et al., 2002; Li et al., 2003; Li and Pan, 2005).

Although we cannot rule out a role for reduced kidney $\mathrm{AT}_{1 \mathrm{a}}$, the hypothalamic gene expression analysis and electrophysiological studies point to a central mechanism. $\mathrm{PVN} \mathrm{AT}_{1 \mathrm{a}}$ deletion reduced CRH and OXT gene expression within the hypothalamus and abolished the Ang-II-induced depolarization of PVN neurons exhibiting neurosecretory or pre-autonomic electrophysiological properties. Interestingly, the probability that neurosecretory and pre-autonomic neurons respond to Ang-II was increased in wild-type mice rendered obese on HFD. Within the $\mathrm{PVN}, \mathrm{AT}_{1 \mathrm{a}}$ influence the activity of neurosecretory (Sumitomo et al., 1991; Aguilera et al., 1995) and pre-autonomic (Cato and Toney, 2005) neurons that are known to express CRH and OXT (Cechetto and Saper, 1988). Elevated Ang-II increases CRH expression (Sumitomo et al., 1991) and activation of CRH receptors induces anorexia, elevates energy expenditure, and enhances sympathetic outflow (Richard et al., 2002; Yamamoto et al., 2011), while antagonism of CRH receptors has the opposite effect (Krahn et al., 1986; Hotta et al., 1999). Similarly, Ang-II influences the activation of OXT neurons and increased OXT produces anorexia and elevates energy expenditure (Olson et al., 1991). These prior studies, in conjunction with our results, suggest that Ang-II influences energy balance during HFD feeding by upregulating the activation of $\mathrm{AT}_{1 \mathrm{a}}$ on $\mathrm{PVN}$ neurons that express CRH or OXT.

Ang-II is a pro-inflammatory factor and inflammation is an important regulator of energy homeostasis (Kim et al., 2008). For example, TNF- $\alpha$ promotes negative energy balance (de Kloet et al., 2011a) and is reduced in PVN AT ${ }_{1 \mathrm{a}} \mathrm{KO}$ mice consistent with a role for inflammation in mediating some of these effects. Additionally, inflammation and microglial activation within the PVN are associated with elevated blood pressure and augmented sympathetic activity (Li et al., 2008; Shi et al., 2010). Given that obesity upregulates the RAS, it is possible that a reduction in Ang-II-induced inflammation enhances the susceptibility to HFD-induced obesity in PVN AT $1 \mathrm{a}$ KO mice. Conversely, increased inflammation and microglial activation may contribute to the enhanced responsiveness of PVN neurons to Ang-II.

The present data reveal a key role of the PVN in the angiotensinergic regulation of energy balance; however, there are other brain nuclei that express $\mathrm{AT}_{1 \mathrm{a}}$ and it is possible that one or more of these play a role in Ang-II's metabolic regulatory action. Yoshida et al. (2012) found that Ang-II produces anorexia by reducing expression of the orexigenic factors, Neuropeptide $\mathrm{Y}$ and orexin, suggesting that the ARC and the lateral hypothalamus may be involved. However, the lack of an effect of genotype on AgRP and POMC levels in the present study suggests that PVN $\mathrm{AT}_{1 \mathrm{a}}$ deletion does not affect the ARC-specific energy balance pathway. The SFO is another potentially important brain nucleus in this regard, as it is critical for communicating the levels of systemic RAS activity to the CNS (Miselis, 1981; Lind et al., 1984; Swanson and Lind, 1986) and has direct projections to the PVN (Krause et al., 2011). The SFO is a potential contributor to the regulation of energy balance (Smith et al., 2009) and a site where adiposity signals like leptin and Ang-II may interact (Hilzendeger et al., 2012). Consequently, the SFO may coordinate systemic and central RAS activity to regulate energy balance.
The RAS has emerged as a key contributor to the regulation of metabolic homeostasis; however, targeting this system as a therapeutic for both pathologies is complicated by the fact that the RAS is present in and has diverse effects on many metabolic tissues. Understanding the distinctive roles of the RAS within various tissues may shed light on how the system can be targeted to treat not only hypertension, but also obesity.

\section{References}

Aguilera G, Young WS, Kiss A, Bathia A (1995) Direct regulation of hypothalamic corticotropin-releasing-hormone neurons by angiotensin-II. Neuroendocrinology 61:437-444. CrossRef Medline

Allen AM, Zhuo J, Mendelsohn FA (1999) Localization of angiotensin AT1 and AT2 receptors. J Am Soc Nephrol 10[Suppl 11]:S23-S29. Medline

Balthasar N, Dalgaard LT, Lee CE, Yu J, Funahashi H, Williams T, Ferreira M, Tang V, McGovern RA, Kenny CD, Christiansen LM, Edelstein E, Choi B, Boss O, Aschkenasi C, Zhang CY, Mountjoy K, Kishi T, Elmquist JK, Lowell BB (2005) Divergence of melanocortin pathways in the control of food intake and energy expenditure. Cell 123:493-505. CrossRef Medline

Boustany CM, Bharadwaj K, Daugherty A, Brown DR, Randall DC, Cassis LA (2004) Activation of the systemic and adipose renin-angiotensin system in rats with diet-induced obesity and hypertension. Am J Physiol Regul Integr Comp Physiol 287:R943-R949. CrossRef Medline

Cato MJ, Toney GM (2005) Angiotensin II excites paraventricular nucleus neurons that innervate the rostral ventrolateral medulla: an in vitro patch-clamp study in brain slices. J Neurophysiol 93:403-413. Medline

Cechetto DF, Saper CB (1988) Neurochemical organization of the hypothalamic projection to the spinal cord in the rat. J Comp Neurol 272:579604. CrossRef Medline

Chen D, Jancovski N, Bassi JK, Nguyen-Huu TP, Choong YT, Palma-Rigo K, Davern PJ, Gurley SB, Thomas WG, Head GA, Allen AM (2012) Angiotensin type $1 \mathrm{~A}$ receptors in $\mathrm{C} 1$ neurons of the rostral ventrolateral medulla modulate the pressor response to aversive stress. J Neurosci 32: 2051-2061. CrossRef Medline

Cooper R, Forrester T, Ogunbiyi O, Muffinda J (1998) Angiotensinogen levels and obesity in four black populations. ICSHIB Investigators. J Hypertens 16:571-575. CrossRef Medline

de Kloet AD, Krause EG, Kim DH, Sakai RR, Seeley RJ, Woods SC (2009) The effect of angiotensin-converting enzyme inhibition using captopril on energy balance and glucose homeostasis. Endocrinology 150:41144123. CrossRef Medline

de Kloet AD, Krause EG, Woods SC (2010) The renin angiotensin system and the metabolic syndrome. Physiol Behav 100:525-534. CrossRef Medline

de Kloet AD, Pacheco-López G, Langhans W, Brown LM (2011a) The effect of TNFalpha on food intake and central insulin sensitivity in rats. Physiol Behav 103:17-20. CrossRef Medline

de Kloet AD, Krause EG, Scott KA, Foster MT, Herman JP, Sakai RR, Seeley RJ, Woods SC (2011b) Central angiotensin-II has catabolic action at white and brown adipose tissue. Am J Physiol Endocrinol Metab.

Furuhashi M, Ura N, Takizawa H, Yoshida D, Moniwa N, Murakami H, Higashiura K, Shimamoto K (2004) Blockade of the renin-angiotensin system decreases adipocyte size with improvement in insulin sensitivity. J Hypertens 22:1977-1982. CrossRef Medline

Grobe JL, Grobe CL, Beltz TG, Westphal SG, Morgan DA, Xu D, de Lange WJ, Li H, Sakai K, Thedens DR, Cassis LA, Rahmouni K, Mark AL, Johnson AK, Sigmund CD (2010) The brain Renin-angiotensin system controls divergent efferent mechanisms to regulate fluid and energy balance. Cell Metab 12:431-442. CrossRef Medline

Hilzendeger AM, Morgan DA, Brooks L, Dellsperger D, Liu X, Grobe JL, Rahmouni K, Sigmund CD, Mark AL (2012) A brain leptin-renin angiotensin system interaction in the regulation of sympathetic nerve activity. Am J Physiol Heart Circ Physiol 303:H197-206. CrossRef Medline

Hoffman NW, Tasker JG, Dudek FE (1991) Immunohistochemical differentiation of electrophysiologically defined neuronal populations in the region of the rat hypothalamic paraventricular nucleus. J Comp Neurol 307:405-416. CrossRef Medline

Hotta M, Shibasaki T, Arai K, Demura H (1999) Corticotropin-releasing factor receptor type 1 mediates emotional stress-induced inhibition of food intake and behavioral changes in rats. Brain Res 823:221-225. CrossRef Medline 
Jayasooriya AP, Mathai ML, Walker LL, Begg DP, Denton DA, CameronSmith D, Egan GF, McKinley MJ, Rodger PD, Sinclair AJ, Wark JD, Weisinger HS, Jois M, Weisinger RS (2008) Mice lacking angiotensinconverting enzyme have increased energy expenditure, with reduced fat mass and improved glucose clearance. Proc Natl Acad Sci U S A 105: 6531-6536. CrossRef Medline

Kasper SO, Carter CS, Ferrario CM, Ganten D, Ferder LF, Sonntag WE, Gallagher PE, Diz DI (2005) Growth, metabolism, and blood pressure disturbances during aging in transgenic rats with altered brain reninangiotensin systems. Physiol Genomics 23:311-317. CrossRef Medline

Kim DH, Sandoval D, Reed JA, Matter EK, Tolod EG, Woods SC, Seeley RJ (2008) The role of GM-CSF in adipose tissue inflammation. Am J Physiol Endocrinol Metab 295:E1038-E1046. CrossRef Medline

Kouyama R, Suganami T, Nishida J, Tanaka M, Toyoda T, Kiso M, Chiwata T, Miyamoto Y, Yoshimasa Y, Fukamizu A, Horiuchi M, Hirata Y, Ogawa Y (2005) Attenuation of diet-induced weight gain and adiposity through increased energy expenditure in mice lacking angiotensin II type la receptor. Endocrinology 146:3481-3489. CrossRef Medline

Krahn DD, Gosnell BA, Grace M, Levine AS (1986) CRF antagonist partially reverses CRF- and stress-induced effects on feeding. Brain Res Bull 17: 285-289. CrossRef Medline

Krause EG, Melhorn SJ, Davis JF, Scott KA, Ma LY, de Kloet AD, Benoit SC, Woods SC, Sakai RR (2008) Angiotensin type 1 receptors in the subfornical organ mediate the drinking and hypothalamic-pituitary-adrenal response to systemic isoproterenol. Endocrinology 149:6416-6424. CrossRef Medline

Krause EG, de Kloet AD, Scott KA, Flak JN, Jones K, Smeltzer MD, Ulrich-Lai YM, Woods SC, Wilson SP, Reagan LP, Herman JP, Sakai RR (2011) Blood-borne angiotensin II acts in the brain to influence behavioral and endocrine responses to psychogenic stress. J Neurosci 31:15009-15015. CrossRef Medline

Latchford KJ, Ferguson AV (2005) Angiotensin depolarizes parvocellular neurons in paraventricular nucleus through modulation of putative nonselective cationic and potassium conductances. Am J Physiol Regul Integr Comp Physiol 289:R52-R58. CrossRef Medline

Lenkei Z, Palkovits M, Corvol P, Llorens-Cortès C (1997) Expression of angiotensin type-1 (AT1) and type-2 (AT2) receptor mRNAs in the adult rat brain: a functional neuroanatomical review. Front Neuroendocrinol 18:383-439. CrossRef Medline

Li DP, Pan HL (2005) Angiotensin II attenuates synaptic GABA release and excites paraventricular-rostral ventrolateral medulla output neurons. J Pharmacol Exp Ther 313:1035-1045. CrossRef Medline

Li DP, Chen SR, Pan HL (2003) Angiotensin II stimulates spinally projecting paraventricular neurons through presynaptic disinhibition. J Neurosci 23:5041-5049. Medline

Li H, Gao Y, Qi Y, Katovich MJ, Jiang N, Braseth LN, Scheuer DA, Shi P, Sumners C (2008) Macrophage migration inhibitory factor in hypothalamic paraventricular nucleus neurons decreases blood pressure in spontaneously hypertensive rats. FASEB J 22:3175-3185. CrossRef Medline

Li H, Weatherford ET, Davis DR, Keen HL, Grobe JL, Daugherty A, Cassis LA, Allen AM, Sigmund CD (2011) Renal proximal tubule angiotensin AT1A receptors regulate blood pressure. Am J Physiol Regul Integr Comp Physiol 301:R1067-R1077. CrossRef Medline

Li P, Morris M, Diz DI, Ferrario CM, Ganten D, Callahan MF (1996) Role of paraventricular angiotensin AT1 receptors in salt-sensitive hypertension in mRen-2 transgenic rats. Am J Physiol 270:R1178-R1181. Medline

Lind RW, Swanson LW, Ganten D (1984) Angiotensin II immunoreactivity in the neural afferents and efferents of the subfornical organ of the rat. Brain Res 321:209-215. CrossRef Medline

Luther JA, Daftary SS, Boudaba C, Gould GC, Halmos KC, Tasker JG (2002) Neurosecretory and non-neurosecretory parvocellular neurones of the hypothalamic paraventricular nucleus express distinct electrophysiological properties. J Neuroendocrinol 14:929-932. CrossRef Medline

Massiera F, Seydoux J, Geloen A, Quignard-Boulange A, Turban S, Saint-Marc P, Fukamizu A, Negrel R, Ailhaud G, Teboul M (2001) Angiotensinogendeficient mice exhibit impairment of diet-induced weight gain with alteration in adipose tissue development and increased locomotor activity. Endocrinology 142:5220-5225. CrossRef Medline

Miselis RR (1981) The efferent projections of the subfornical organ of the rat: a circumventricular organ within a neural network subserving water balance. Brain Res 230:1-23. CrossRef Medline

Olson BR, Drutarosky MD, Stricker EM, Verbalis JG (1991) Brain oxytocin receptor antagonism blunts the effects of anorexigenic treatments in rats: evidence for central oxytocin inhibition of food intake. Endocrinology 129:785-791. CrossRef Medline

Porter JP, Potratz KR (2004) Effect of intracerebroventricular angiotensin II on body weight and food intake in adult rats. Am J Physiol Regul Integr Comp Physiol 287:R422-R428. CrossRef Medline

Porter JP, Anderson JM, Robison RJ, Phillips AC (2003) Effect of central angiotensin II on body weight gain in young rats. Brain Res 959:20-28. CrossRef Medline

Rahmouni K, Mark AL, Haynes WG, Sigmund CD (2004) Adipose depotspecific modulation of angiotensinogen gene expression in diet-induced obesity. Am J Physiol Endocrinol Metab 286:E891-E895. CrossRef Medline

Richard D, Lin Q, Timofeeva E (2002) The corticotropin-releasing factor family of peptides and CRF receptors: their roles in the regulation of energy balance. Eur J Pharmacol 440:189-197. CrossRef Medline

Sarruf DA, Thaler JP, Morton GJ, German J, Fischer JD, Ogimoto K, Schwartz MW (2010) Fibroblast growth factor 21 action in the brain increases energy expenditure and insulin sensitivity in obese rats. Diabetes 59: 1817-1824. CrossRef Medline

Shi P, Diez-Freire C, Jun JY, Qi Y, Katovich MJ, Li Q, Sriramula S, Francis J, Sumners C, Raizada MK (2010) Brain microglial cytokines in neurogenic hypertension. Hypertension 56:297-303. CrossRef Medline

Smith PM, Chambers AP, Price CJ, Ho W, Hopf C, Sharkey KA, Ferguson AV (2009) The subfornical organ: a central nervous system site for actions of circulating leptin. Am J Physiol Regul Integr Comp Physiol 296:R512-R520. Medline

Stern JE (2001) Electrophysiological and morphological properties of preautonomic neurones in the rat hypothalamic paraventricular nucleus. J Physiol 537:161-177. CrossRef Medline

Sumitomo T, Suda T, Nakano Y, Tozawa F, Yamada M, Demura H (1991) Angiotensin-II increases the corticotropin-releasing factor messengerribonucleic-acid level in the rat hypothalamus. Endocrinology 128:2248-2252. CrossRef Medline

Swanson LW, Lind RW (1986) Neural projections subserving the initiation of a specific motivated behavior in the rat: new projections from the subfornical organ. Brain Res 379:399-403. CrossRef Medline

Taicher GZ, Tinsley FC, Reiderman A, Heiman ML (2003) Quantitative magnetic resonance (QMR) method for bone and whole-bodycomposition analysis. Anal Bioanal Chem 377:990-1002. CrossRef Medline

Takahashi N, Li F, Hua K, Deng J, Wang CH, Bowers RR, Bartness TJ, Kim HS, Harp JB (2007) Increased energy expenditure, dietary fat wasting, and resistance to diet-induced obesity in mice lacking renin. Cell Metab 6:506-512. CrossRef Medline

Tasker JG, Dudek FE (1991) Electrophysiological properties of neurones in the region of the paraventricular nucleus in slices of rat hypothalamus. J Physiol 434:271-293. Medline

Weisinger HS, Begg DP, Egan GF, Jayasooriya AP, Lie F, Mathai ML, Sinclair AJ, Wark JD, Weisinger RS (2008) Angiotensin converting enzyme inhibition from birth reduces body weight and body fat in Sprague-Dawley rats. Physiol Behav 93:820-825. CrossRef Medline

Woods SC, D’Alessio DA (2008) Central control of body weight and appetite. J Clin Endocrinol Metab 93:S37-S50. CrossRef Medline

Yamamoto R, Akazawa H, Fujihara H, Ozasa Y, Yasuda N, Ito K, Kudo Y, Qin Y, Ueta Y, Komuro I (2011) Angiotensin II type 1 receptor signaling regulates feeding behavior through anorexigenic corticotropin-releasing hormone in hypothalamus. J Biol Chem 286:21458-21465. CrossRef Medline

Yoshida T, Semprun-Prieto L, Wainford RD, Sukhanov S, Kapusta DR, Delafontaine P (2012) Angiotensin II reduces food intake by altering orexigenic neuropeptide expression in the mouse hypothalamus. Endocrinology 153:1411-1420. CrossRef Medline

Yvan-Charvet L, Even P, Bloch-Faure M, Guerre-Millo M, Moustaid-Moussa N, Ferre P, Quignard-Boulange A (2005) Deletion of the angiotensin type 2 receptor (AT2R) reduces adipose cell size and protects from dietinduced obesity and insulin resistance. Diabetes 54:991-999. CrossRef Medline

Zhu GQ, Patel KP, Zucker IH, Wang W (2002) Microinjection of ANG II into paraventricular nucleus enhances cardiac sympathetic afferent reflex in rats. Am J Physiol Heart Circ Physiol 282:H2039-H2045. Medline 